\title{
RECESSION OF GLACIER TASÎSSÂRSSIK A, EAST GREENLAND
}

\author{
By P. W. F. GRibBon \\ (Department of Natural Philosophy, St. Salvator's College, \\ University of St. Andrews, St. Andrews, Fife, Scotland)
}

\begin{abstract}
The maximum diameters of a lichen of known growth rate have been measured on the bedrock flanking glacier Tasissârssik A (lat. $66^{\circ} \mathrm{o6} 6^{\prime}$ N., long. $36^{\circ} 5^{8^{\prime}}$ W.) in East Greenland. The estimated age of the lateral trimline of this glacier is $\mathrm{I} 33 \pm 20 \mathrm{yr}$, , indicating that the recent recession of this and other glaciers in the Caledonian alps, East Greenland, appears to be synchronous with the overall recession in West Greenland.
\end{abstract}

RÉsumé. Les plus grandes dimensions d'un lichen dont le taux de croissance est connu, ont été mesurées sur le socle rocheux bordant le glacier Tasîssâssik A (lat. $66^{\circ} 06^{\prime} \mathrm{N}$, long. $36^{\circ} 5^{8^{\prime}} \mathrm{W}$ ), à l'Est du Groenland. On a évalué l'âge de la moraine latérale de ce glacier à $133 \pm 20$ ans, ce qui montre que la récente régression de ce glacier et d'autres des alpes calédoniennes à l'Est du Groenland, apparaît comme étant synchronisée avec la régression globale de l'Ouest de Groenland.

Zusammenfassung. Auf den Felsflanken des Gletschers Tarîssârssik A in Ost-Grönland (Breite 66 o6 $6^{\prime} \mathrm{N}$, Länge $36^{\circ} 5^{8^{\prime} \mathrm{W}}$ ) wurden die Maximal-Durchmesser von Flechten bekannter Wachstumsgeschwindigkeit gemessen. Das Alter der seitlichen Begrenzungslinie dieses Gletschers beträgt schätzungsweise $133 \pm 20$ Jahre. Hierin ist ein Anzeichen dafür zu sehen, dass der rezente Rückzug dieses und anderer Gletscher in den Caledonischen Alpen von Ost-Grönland in zeitlicher Ubereinstimmung mit dem allgemeinen Rückzug in West-Grönland verlaufen ist.

RECENTLY it has become possible to obtain a reliable estimate of the time that has elapsed since a glacier started to retreat by measuring the size of certain crustaceous lichens growing in the glacier foreland (see the review article by Beschel (I96I)). The longer the time that has elapsed since the recession, the larger, and hence the older will be the lichens growing in the foreland. If the growth rate of the lichen in the macroclimatic conditions prevailing in the foreland is known, the date at which the lichen started to grow on the freshly exposed rock surfaces can be estimated.

Measurements of the lichen size, etc., that have been obtained in the European Alps, Ruwenzori mountains and West Greenland show that the behaviour of the glaciers in these regions within the last four centuries appears to be synchronous, and it is to be expected that glaciers elsewhere would show a similar sychronism. This note presents information on the behaviour of the glaciers of the Tasîssârssik valley of the Caledonian alps, a mountainous region centred about lat. $66^{\circ}$ Io' N., long. $37^{\circ} 45^{\prime}$ W. in Kong Christian IX's Land, East Greenland. Their behaviour indicates that rapid glacier recession in this region began I 33 yr. B.P. in synchronization with the overall recession in West Greenland (Weidick, I959; Beschel, I96r, p. г057-6o).

The valley in continuation of the Tasîssârssik inlet of the Angmagssalik Fjord receives several valley glaciers draining down from the alpine mountains on either side (Danmark Geodætisk Institut maps, Grönland I:250,00o, 66 Ö 2 Schweizerland; I:50,ooo 66 Ö 2-o). Böcher (1956, p. 13) has considered that during the last glacial age the Tasîssârssik valley acted as a drainage valley for ice moving from the western fringes of the Caledonian alps and so prevented extensive glaciation of the neighbouring western Qíngorssuaq valley, which thereby was able to remain free from continuous ice cover and to function as a plant refugium. However, since the flow patterns and accumulation areas of the glaciers in the western fringes of the Caledonian alps are limited by physiographic features, it is also likely that the Tasîssârssik valley was not heavily glaciated in the last ice age, a conclusion supported by both geomorphological and botanical evidence obtained in the Tasîssârssik valley. Three local valley glaciers were studied, all of which show recent recession by the distribution, position and height of their terminal and lateral moraines. The glaciers, which terminate sharply 
with little outwash, reach close to the main valley floor and each has three relatively closely spaced terminal moraines, which are considered to be contemporaneous physiographic features for the three glaciers.

The time that has elapsed since the recession began was obtained from lichen-size measurements made on the lateral trimline of one of these glaciers, Tasîssârssik A, at lat. $66^{\circ} 05^{\prime}$ $56^{\prime \prime} \mathrm{N}$., long. $36^{\circ} 5^{8^{\prime}} \mathrm{r}^{\prime \prime} \mathrm{W}$. The trimline was on gently dipping gneiss at $805 \mathrm{~m}$. above the accumulation area $\left(2 \cdot 2 \mathrm{~km}^{2}\right)$ of the glacier, and the maximum diameters of lichen thalli of the collective species Rhizocarpon geographicum were measured at various heights above the glacier firn, as shown in Figure $\mathrm{I}$. The maximum diameter at the trimline is $\mathrm{I} 6 \pm \mathrm{I} \mathrm{mm}$., and

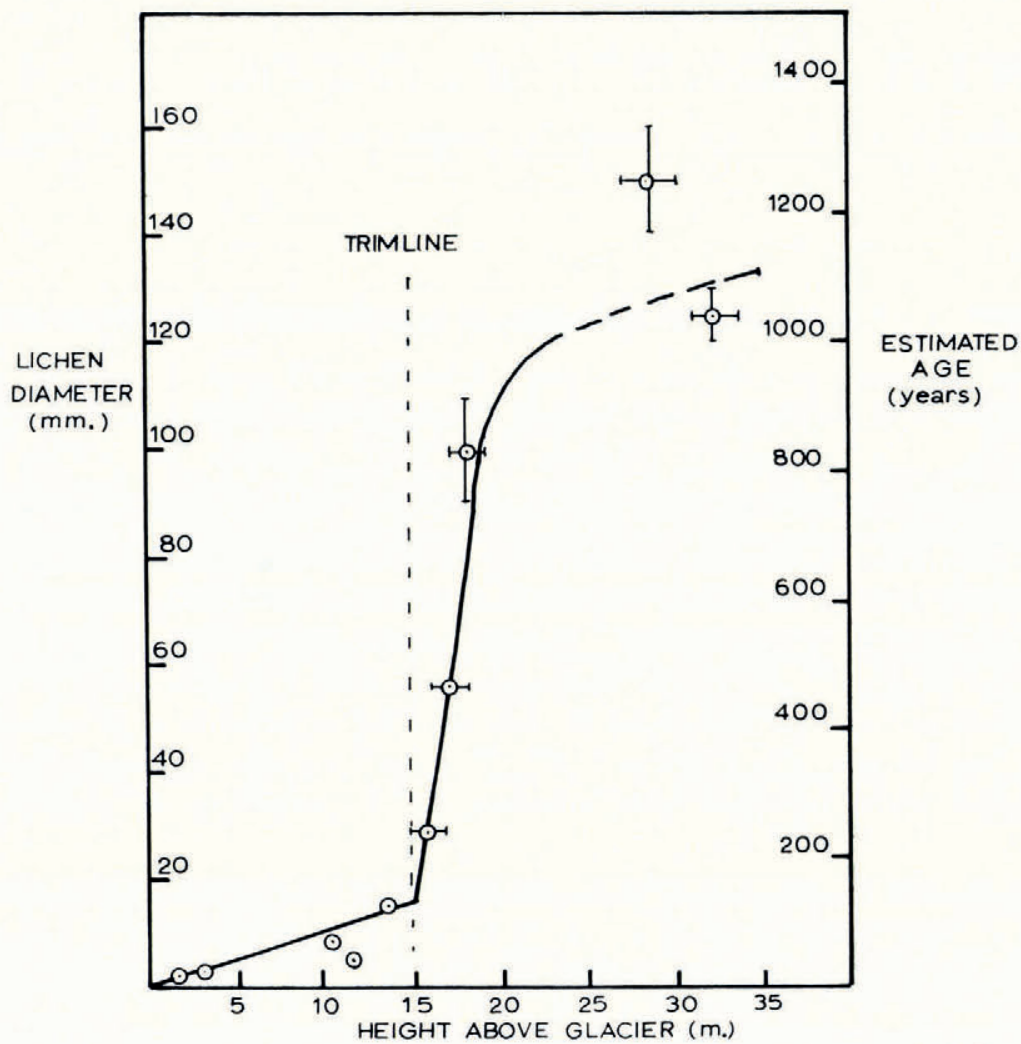

Fig. I. The variation of lichen size and age with height above the firn of glacier Tasîssârssik A, East Greenland

the trimline occurs at $14 \cdot 3 \pm 0 \cdot 7 \mathrm{~m}$. above the glacier. The age of a lichen of this diameter is $\mathrm{I} 33 \pm 20$ yr., assuming a maximum growth rate of $\mathrm{I} 2 \pm \mathrm{I} \mathrm{mm}$. per century for Rhizocarpon geographicum coll. (Beschel, I958, I961). Their growth rate on the exposed bedrock surfaces flanking the glacier is inversely proportional to their height above sea-level $\left(80_{5} \mathrm{~m}\right.$.) and the distance from the open sea $(45 \pm 5 \mathrm{~km}$.) or to the hygrocontinentality, i.e. the climatic factor expressing the humidity of the lichen environment in terms of the temperature and annual precipitation, at the height of the glacier flank. The higher annual precipitation combined with a similar summer temperature make it likely that the growth rates per century in East Greenland are slightly greater than in the same latitude in West Greenland, and thus the growth rate per century at Tasîssârssik A will be comparable with the I I mm. per century growth rate for Rhizocarpon tinei measured $47 \mathrm{~km}$. from the open sea at $870 \mathrm{~m}$. on the moraines of glacier Tunugdliarfik E (lat. $66^{\circ} 27^{\prime}$ N.) in West Greenland (Beschel, I958, I96r, fig. I). 
The rate of plant recolonization on the exposed rock also depends on the time that has elapsed since exposure (Hale, 1952; Beschel, 1957; Stork, I963). The trimline was on the gentle eastern slope of an isolated rock outcrop at $830 \mathrm{~m}$., and 26 species of vascular plants were collected in the abundant xerophytic vegetation on the sheltered southern ledges. Ten of these species now occur at the trimline, while five species (Salix arctophila, Salix herbacea, Trisetum spicatum, Luzula confusa and Oxyria digyna) have been established $40 \mathrm{~m}$. east of the trimline on sandy patches $2 \mathrm{~m}$. above the glacier firn. Lichen dating shows that the latter plant immigration occurred within the last $20 \mathrm{yr}$.

The age of the trimline and its height above the glacier give through Figure $\mathrm{I}$ an estimated mean recession rate of the glacier surface, and hence of its transverse profile of I I $\mathrm{cm}$. $/ \mathrm{yr}$. since the recession date A.D. $1830 \pm 20$. This is a thirty-fold increase in recession rate, since before A.D. I 830 the mean recession rate was only $0.4 \mathrm{~cm}$. $/ \mathrm{yr}$. It represents a net volume ablation loss in the accumulation area of the same order of magnitude as the volume loss at the glacier front, there being a $900 \mathrm{~m}$. recession between the outer terminal moraine and the present position of the glacier ice (photographs: Danmark Geodætisk Institut aerial GRE37-I25/8; survey, I 963 Scottish East Greenland Expedition, I 5 July ig63).

In conclusion, it is emphasized that further and more extensive glaciological and lichenometric work is required to confirm the overall synchronism of glacier behaviour in West and East Greenland.

MS. received 6 February 1964

\section{REFERENCES}

Beschel, R. E. I 957. Lichenometrie im Gletschervorfeld. Fahrbuch des Vereins zum Schutze der Alpenpflanzen und Tiere München, Bd. 22, p. I64-85.

Beschel, R. E. 1958. Lichenometrical studies in West Greenland. Arctic, Vol. 11, No. 4, p. 254.

Beschel, R. E. 196I. Dating rock surfaces by lichen growth and its application to glaciology and physiography (lichenometry). (In Raasch, G. O., ed. Geology of the Arctic. Proceedings of the first International Symposium on Arctic Geology. Toronto, University of Toronto Press, 1961, Vol. 2, p. 1044-62.)

Böcher, T. W. 1956. Area-limits and isolations of plants in relation to the physiography of the southern parts of Greenland. Meddelelser om Gronland, Bd. 124, Nr. 8.

Hale, M. E. 1952. The glaciological studies of the Baffin Island Expedition, 1950. Part II. Appendix. Moraine plant succession at the edge of the ice cap. Journal of Glaciology, Vol. 2, No. I 1, p. 22-23.

Stork, A. 1963 . Plant immigration in front of retreating glaciers, with examples from the Kebnekajse area, northern Sweden. Geografiska Annaler, Vol. 45, No. I, p. I-22.

Weidick, A. 1959. Glacial variations in West Greenland in historical time. Part I. Southwest Greenland. Meddelelser om Gronland. Bd. 158, Nr. 4. 